\title{
Decomposing the Macroeconomic Effects of Natural Disasters: A National Income Accounting Perspective
}

DOI:

10.1016/j.ecolecon.2017.09.011

\section{Document Version}

Accepted author manuscript

Link to publication record in Manchester Research Explorer

\section{Citation for published version (APA):}

Mohan, P. S., Ouattara, B., \& Strobl, E. (2018). Decomposing the Macroeconomic Effects of Natural Disasters: A National Income Accounting Perspective. Ecological Economics, 146, 1-9.

https://doi.org/10.1016/j.ecolecon.2017.09.011

\section{Published in:}

Ecological Economics

\section{Citing this paper}

Please note that where the full-text provided on Manchester Research Explorer is the Author Accepted Manuscript or Proof version this may differ from the final Published version. If citing, it is advised that you check and use the publisher's definitive version.

\section{General rights}

Copyright and moral rights for the publications made accessible in the Research Explorer are retained by the authors and/or other copyright owners and it is a condition of accessing publications that users recognise and abide by the legal requirements associated with these rights.

\section{Takedown policy}

If you believe that this document breaches copyright please refer to the University of Manchester's Takedown Procedures [http://man.ac.uk/04Y6Bo] or contact uml.scholarlycommunications@manchester.ac.uk providing relevant details, so we can investigate your claim.

\section{OPEN ACCESS}




\title{
Decomposing the Macroeconomic Effects of Natural Disasters:
}

\author{
A National Income Accounting Perspective \\ Preeya Mohan (Sir Arthur Lewis Institute of Social and Economic Studies, University of the \\ West Indies, St. Augustine) \\ Bazoumana Ouattara (Global Development Institute University of Manchester) \\ Eric Strobl (Dept. of Economics and OCCR, University of Bern)
}

\begin{abstract}
There is an unresolved debate as to whether natural disasters present true obstacles to a country's economic growth and development, given that the empirical evidence is rather heterogeneous. In this paper we explore whether aggregate analyses are likely to mask different responses of the components (export and import, government consumption, investment and private consumption) of Gross Domestic Product (GDP). To this end, we assembled a panel data set of hurricane strikes and national income accounting data for 21 Caribbean countries for the period 1970-2011. We used a panel Vector Autoregressive (VARX) model to take account of the direct impact of the storm shocks and any feedback mechanisms. Our results suggest that the responses on each GDP component differ widely, where we find some effects on export, import, public consumption, investment and private consumption. However, the differences in timing and directions of these impacts demonstrate why it may be difficult to find any clear and large net aggregate impact of hurricanes and natural disasters in general on GDP.
\end{abstract}




\section{Section I: Introduction}

While published figures on total damages and losses due to natural disasters tend often to be large, the actual macroeconomic impact is as of date not yet clear. More precisely, although there is now a sizeable academic literature examining the economic wealth and growth impacts of natural disasters, the derived results are rather mixed. For instance, AlbalaBertrand (1993) and Skidmore and Toya (2002) found some growth increases following a natural disaster, while results from Raddatz (2007), Noy (2009), and Noy and Nualsri (2007) indicate small, short-lived negative effects. Importantly, from a policy perspective this inconclusiveness is arguably rather worrying, as it makes it difficult to confidently identify how much of a role ex-ante and/or ex-post disaster mitigation could and should play in dealing with these extreme events. This is even more so in view of the fact that developing countries are disproportionately more negatively affected by natural disasters (Loayza et al. 2012 and Noy 2009) and thus, such shocks could further undermine their catch-up to the developed world or, even worst, induce poverty traps (Noy 2009, Anbarci et al. 2005, Kahn 2005, Skidmore and Toya 2007 and Carter et al. 2007).

There could of course be many reasons for the rather mixed evidence in the literature with regard to the macroeconomic impact of natural disasters. The most obvious ones are purely empirical: heterogeneity in data samples, use of different natural disaster event proxies, and employment of different econometric methodologies. And indeed, in their meta-analysis of over 750 natural disaster estimates Klomp and Valckx (2014) observed that studies differ widely with respect to the types of disaster, sample of countries, time periods, model specifications, and estimators. There could, however, also be another, non-methodological, reason, in that any purely macroeconomic approach, where the response variable is captured by country level Gross Domestic Product (GDP) per capita levels or growth rates, as in most 
studies, inherently masks the potentially heterogeneously responding forces of the underlying system. More precisely, different economic sectors, actors, and channels may respond very differently to potentially large and unanticipated shocks to physical and human capital such as a natural disaster. As a matter of fact, the still somewhat scarce but growing literature disentangling the effect of natural disasters beyond the purely aggregate suggests that response heterogeneity may be an important characteristic driving the effects. For example, Loayza et al. (2012) showed that natural disasters affect economic growth differently across sectors.

In this paper we explicitly investigate the degree of potential heterogeneity of sub-aggregate responses to natural disasters by taking a national income accounting (NA) approach. More specifically, we econometrically disentangle how each of the national income components, i.e., export, import, public consumption, private investment and private consumption respond to natural disaster shocks. There is of course no reason one should expect the NA components of GDP to react in the same way. For instance, the physical damages caused by natural catastrophes could induce private and public investment to rise as part of reconstruction efforts and in turn possibly require greater import of reconstruction related material and services. At the same time, the immediate losses in revenue due to the disruption in economic activity could induce a fall in private savings, and hence investment, as well as fiscal shortages.

In terms of empirical evidence, there are of course already a handful of studies that have specifically looked at the effect of natural disasters on the components that make up GDP. For instance, Narayan (2003) examined the macroeconomic impact of Typhoon Ami on Fiji in 2003 and concluded that export, import, private investment, and private consumption all 
decreased. Gassebner et al. (2010) in a study of trade flows found a negative impact on import and export. On the other hand, Noy (2009) showed that in some cases investment increased (reconstruction investment) and in other cases decreased (perceptions in likelihood of future disasters) after natural disasters, and similarly, for export and import the results were inconclusive. Importantly, however, none of these studies have investigated the effects as part of an underlying system of macroeconomic activity, thereby allowing for the possibility of interdependencies and feedback effects among the components. Not doing so arguably makes it difficult to quantitatively assess how the underlying factors jointly produce any macroeconomic impact.

To undertake our NA decomposition analysis we build a panel data set covering over 50 years of hurricane events and GDP components for 21 Caribbean countries. Our econometric strategy to investigate to what extent heterogeneous responses in the NA components might be driving these small aggregate and short-lived effects is to use a panel Vector Autoregressive with an exogenous shock (VARX) framework. Importantly in this regard, the panel VARX model allows one to not only incorporate the direct effect of hurricanes on each component but also capture feedback effects within the whole system. Arguably, the Caribbean presents an ideal case study for the task at hand. Firstly, the region is located in the North Atlantic Ocean hurricane belt and as such has been singled out as one of the most disaster-prone territories in the world, on account of the large number of hurricanes experienced. As a matter of fact, according to Rasmussen $(2004,3)$ "since 1970 a natural disaster inflicting damage equivalent to more than $2 \%$ of the affected country's GDP can be expected roughly every 2.5 years [in the region]." Secondly, as a set of Small Island Developing States (SIDS) characterized by large debts, high trade openness, low and variable investment, strong dependence on foreign aid and Foreign Direct Investment, and general consumption 
volatility, Caribbean countries tend to be very susceptible to external shocks (Briguglio et al. 2006, Auffret 2003 and Easterly and Kraay 2000), where climatic shocks have been shown to be the most cataclysmic.

Despite the potential high vulnerability of Caribbean islands to tropical storms, existing empirical evidence, somewhat surprisingly, suggests that the actual impact of hurricanes in the Caribbean is rather small, where studies such as Hsiang (2010), Strobl (2012), and Bertinelli and Strobl (2013) suggest that these generally only induce short-term falls in GDP of no more than a few percentage points. There are, however, a small number of papers, specifically focusing on the Caribbean, that already suggest that the reaction of the different components underlying GDP may be fairly heterogeneous. For example, Crowards (2000), examined averages across 21 destructive hurricanes in the region from 1970 to 1997, and found a negative impact on export and import, while net foreign assets increased, inflation remained the same and the impact on government expenditure was not clear. Heger et al. (2008) employed panel data techniques for 16 Caribbean countries and concluded that the fiscal balance, trade balance and the capital stock were negatively affected. Rasmussen (2004) investigated the impact of 12 large natural disasters in the Eastern Caribbean from 1970 to 2004 and found a rise in investment and import, while export decreased, and there was no clear impact on government expenditure. Finally, Auffret (2003) studied 6 Caribbean and 10 Latin American countries and showed that natural disasters result in a substantial decline in investment, a moderate decline in consumption (mainly in private consumption and moderately in public consumption) and a worsening of the current account resulting from a larger decrease in export compared to import. The conclusion derived from the above studies demonstrates that there is indeed a lot of heterogeneity in terms of both the direction and the timing of the effect of hurricanes on the components of GDP and that it is thus not 
surprising that in aggregate it is difficult to find a large impact.

The remainder of the paper is organized as follows. Section 2 provides details on the hurricane destruction index and data sources and summary statistics. Section 3 presents the empirical strategy. Section 4 gives the results. Finally, Section 5 concludes.

\section{Section II: Data and Summary Statistics}

\section{A. Hurricane Destruction Index}

Our study requires a measure of hurricane destruction. In earlier studies destruction due to tropical storms was measured either using ex-post damage estimates, such as those found in the Emergency Events Database (EMDAT), or fairly generic characteristics of the storm, such as incidence of landfall dummy or total maximum wind speed (Loayza et al. 2012, Hochrainer 2009, Noy 2009, Raddatz 2007, Noy and Nualsri 2007, Rasmussen 2004, Skidmore and Toya 2002 and Albala-Bertrand 1993). However, both approaches are likely to be problematic. For example, with regard to the former, it is now widely recognized that the ex-post damage estimates can induce endogeneity problems. Using ex-post measures, such as EMDAT, can produce biased results (Strobl 2012). In terms of the latter, generic storm characteristics are likely to oversimplify the differing complexities of a storm and spatial heterogeneity in terms of exposure to their impact. Moreover, one should take into account the considerable heterogeneity of damage a storm can cause even within countries, particularly, since economic activity is unlikely to be evenly distributed. To circumvent these problems, and take these aspects into account we here follow Strobl (2012), and explicitly model the physical characteristics of a storm and also took into account the ex-ante economic exposure to damage. We constructed a hurricane destruction index, which is based on estimated localised wind speeds derived from actual hurricane tracks to which a wind field model was applied. 
We consider our hurricane destruction index to be a more scientifically based proxy of potential local destruction. More precisely, we used each of the storms through time and space and adopted the wind field model proposed by Boose et al. (2004) to derive local wind experienced within Caribbean states, which given a hurricane track can provide for each point in time of a hurricane's lifespan a value of wind speed experienced at any location on land. To this end the model used information on the maximum wind speed, traveling speed, traveling direction and whether the storm made landfall. The degree of wind exposure is then translated into potential damages using a damage function, weighted according to the share of population exposed to derive a country wide hurricane damage proxy. For details of this modelling process we refer readers to the Appendix.

In terms of then translating these local wind speeds into potential local damages, one should note that property damage due to winds during a tropical storm should vary with the cubic power of the wind speed on physical grounds, and it is for this reason that many previous studies have simply used the cubic power of wind speed experienced as a destruction proxy. ${ }^{1}$ However, there is likely to be a threshold below which it is improbable that there is any substantial physical damage (Emanuel 2011). Moreover, the fraction of property damaged should approach unity at very high wind speeds. To incorporate these aspects we employed the damage index, $f$, proposed by Emanuel (2011), which proxies the fraction of property damaged as a function of wind speed, $V$ :

$f_{i j k}=\frac{v_{i j k}^{3}}{1+v_{i j k}^{3}}$

Where

\footnotetext{
${ }^{1}$ See Elliott et al. (2015) for details.
} 
$v_{i j k}=\frac{\operatorname{MAX}\left[\left(V_{i j k}-V_{\text {thresh }}\right), 0\right]}{V_{\text {half }}-V_{\text {thresh }}}$

where $V_{i k t}$ is the maximum wind experienced at point $i$ in country $k$ due to storm $j, V_{\text {thresh }}$ is the threshold below which no damage occurs, and $V_{\text {half }}$ is the threshold at which half of the property is damaged. Given the maximum wind speed, the functional form in (2) will depend on the choice of parameters $V_{\text {thresh }}$ and $V_{\text {half. }}$. Emanuel (2011) suggested that for $V_{\text {thresh }}$ there is unlikely to be any damage for winds below $50 \mathrm{kts}$ (i.e., $92 \mathrm{~km} / \mathrm{h}$ ) and we thus similarly used this cut-off point. For $V_{\text {half }}$ we also followed Emanuel (2011) and used $203 \mathrm{~km} / \mathrm{hr}$.

Since assets/population are unlikely to be homogenously distributed within islands we need to take account not only of local wind speed experienced but also of differences in exposure, when generating an island wide proxy of destruction. Our island level potential destruction proxy is thus:

$$
f_{j t}=\Sigma_{k \epsilon t} \Sigma_{i=1}^{N} w_{i k t-1} f_{i j k}
$$

where $w_{i k t-1}$ is the share of population at point $i$ in year $t-1$ in island $k$. One may want to note that we explicitly used the population weight at $t-1$ rather than $t$ so as to avoid that our weights are (ex-post) influenced by the hurricane shocks and thus potentially endogenous.

Our wind field model and ultimately our damage proxies require hurricane tracks. For these we used the Hurricane database (HURDAT), which provides hurricane track data on all known storms in the North Atlantic Ocean Basin since 1850. For each storm the database provides information on the time and location of the hurricane eye and the maximum wind speed for every six hour interval of the storm's lifespan.

To derive local exposure weights we, as in Strobl (2012), used the Latin American and 
Caribbean Population database (CIAT) which provides population estimates at the $1 \mathrm{~km}$ grid cell level for 1950, 1960, 1970, 1980, 1990, and 2000 for the Caribbean. We interpolated the cell level values to annual values between given data years. Shares $(w)$ were then calculated as the annual share of total population in a cell of a country.

\section{B. GDP Components}

For information on GDP components we used the Penn World Tables (PWT) (version 8.1). More specifically, the PWT provides us with annual export (Export) which measures the share of merchandise export, import (Import) which measures the share of merchandise import, government consumption (Govcons) which measures the share of government consumption, investment (Inv) which measures the share of gross capital formation, and private consumption (Privcons) which measures the share of household consumption, all relative to GDP. All variables are at current Purchasing Power Parity (PPP), deflated to 2005 values, measured in millions of US dollars. The PWT uses detailed prices within each country for each expenditure category, regardless of whether the output is traded internationally. These detailed prices are combined into an overall relative price to create the country's PPP exchange rates, and one is therefore able to convert GDP at national prices into US dollars making it internationally comparable across all countries. In terms of the Caribbean, the data cover the following countries: Aruba, Anguilla, Antigua and Barbuda, the Bahamas, Barbados, British Virgin Islands, Cuba, Cayman Islands, Dominica, Dominican Republic, Grenada, Haiti, Jamaica, Montserrat, Puerto Rico, St. Kitts and Nevis, St. Lucia, St. Vincent and the Grenadines, the Netherlands Antilles, Trinidad and Tobago and Turks and Caicos Islands. These make up our sample of countries in the analysis. 


\section{Summary Statistics}

Table 1 shows key summary statistics (mean, standard deviation and minimum and maximum values) for the dependent and independent variables used in the study. Private consumption has the largest mean and standard deviation, followed by import, export, investment, and government consumption. The hurricane destruction index has a mean value of 0.21 with a standard deviation of 0.41 and a maximum value of 3.68. We depict the distribution of the average annual value in Figure 1. As can be seen, the amount of destruction that islands experienced over our time period varied substantially.

\section{Section III: Econometric Methodology}

To capture the dynamic response of our macroeconomic variables to hurricane shocks we used a panel VAR framework, which accommodates external shocks. Since the objective of this paper is to investigate the impact of natural disasters, in particular hurricanes on the subcomponents of national income our model included each of the 5 GDP components, export, import, government consumption, investment and private consumption as the dependent variable. These variables are measured using data from the PWT in current PPP, deflated to 2005 values, measured in millions of US dollars. The model included one independent variable, which is our hurricane destruction index. The index provides a localised measure of hurricane destruction in terms of wind speed and is arguably exogenous given that it is solely dependent on global climatic factors. We also included time and country specific effects to account for time invariant country specific unobservables and time specific unobservables

common to all countries. To illustrate, the reduced form VARX takes the following specification: 
$y_{t}=\psi+\sum_{j=1}^{p} \beta_{j} y_{t-j}+\sum_{k=0}^{s} \pi_{k} x_{t-k}+\mathrm{v}_{t}$

where $y$ represents the vector of endogenous variables, namely export (Export), import (Import), government consumption (Govcons), investment (Inv), and private consumption (Privcons), $x$ is our exogenous variable, the hurricane index $(f) ; t$ stands for time; and $v$ represents the error term of the system. Taking into account the panel structure of our data, and accounting for fixed-effects, Equation (1) can be re-written as:

$y_{i, t}=\psi_{i}+\sum_{j=1}^{p} \beta_{i, j} y_{i, t-j}+\sum_{k=0}^{S} \pi_{k} x_{i, t-j}+\mathrm{v}_{i, t}$

where $i$ is the country index and $\psi_{i}$ captures the fixed effect for each country. Further, one can write the multiplier form of the above equation as follows:

$y_{i, t}=\Omega(L)^{-1} \Phi(L) x_{i, t}+\Omega(L)^{-1} \sigma_{i, t}$

where $L$ stands for the lag operator. The mean response of a hurricane shock is, therefore, captured by the polynomial term $\Omega(L)^{-1} \Phi(L)$.

The panel data model adopted here is dynamic, albeit with a restricted time dimension. This may result in biased and inconsistent results if fixed effects are treated in the usual way (Nickell 1981 and Kiviet 1995). While the bias might not be large in very large samples it is likely a problem in small samples like the one used in this paper. ${ }^{2}$ To overcome this concern we used a bias-corrected Least Squares Dummy Variable (LSDV) estimator, where boostrap standard errors were estimated following the suggestion by Pesaran and Zhao (1999) and Everaert and Pozzi (2007).

\footnotetext{
2 Judson and Owen (1991) showed that for a sample size $\mathrm{N}=30$ the size of the bias could be around $20 \%$ of the true value of the estimated coefficient.
} 
A critical assumption of the panel VARX technique adopted in this paper is that the endogenous variables included in model (2) must be stationary. Consequently, it is important to test for the order of integration of the variables before proceeding to the estimation stage. For this purpose, we consider two widely used unit root tests, i.e., the Levin et al. (2002)Levin, Lin and Chu (LLC) and the Pesaran (2007)- cross-sectionally augmented Im, Pesaran and Shin (CIPS) panel unit root tests. A fundamental difference between the LLC and the CIPS tests is that while the former assumes that the individual time series in the panel are crosssectionally independently distributed, the latter assumes cross-sectional dependence as well as serially correlated errors. The basic framework followed by these tests can be viewed as an extension of the standard (augmented) Dickey Fuller test and takes the following form:

$\Delta w_{i t}=g_{i t} \delta+\varphi_{i} w_{i t-1}+\sum_{j=1}^{k} \pi_{i j} \Delta w_{i t-1}+\vartheta_{i t}$

where $w_{i t}$ denotes each variable under consideration, $k$ is the lag length, the vector $g_{i t}^{\prime}$ includes panel-specific fixed-effects or panel-specific fixed time effects and $\delta$ is the corresponding vector of coefficients.

The LLC test assumes the coefficient of the auto-regressive term to be homogeneous across all $i$ (i.e $\varphi_{i}=\varphi$ ) and examines the null hypothesis of $H_{0}: \varphi=0$, against the alternative $H_{1}: \varphi<0$. The Pesaran (2007) test addresses cross-sectional dependence by including the cross-sectional mean of the lagged values of $w_{i t}$ and its differences. The corresponding test is then defined as the simple average of the individual cross-section ADF regressions: $C A D F=$ $\frac{1}{N} \Sigma_{i-1}^{t_{i}}$, where $t_{i}$ is the t-statistics of the Ordinary Least Square (OLS) estimate of the autoregressive term in the modified version of Equation (4).

Another important step in our empirical approach is the lag structure of the panel VARX 
model. However, it is well known that in the presence of incidental parameters like fixedeffects standard lag selection criteria such as the bayesian information criteria (BIC) can be unreliable (see Han et al. 2017 for a detailed discussion). In order to circumvent this issue we adopted the consistent and robust BIC, and the sequential lag selection criteria based on the general-to-specific (GS) approach, both of which were proposed by Han et al. (2017).

\section{Section IV: Results}

We start by first discussing the panel unit root tests and lag selection results, which are portrayed in Table 2, Panels A and B. Recall that the implementation of our panel VARX requires the endogenous variables to be stationary. It can be seen from Table 2 (Panel-A) both the LLC and the CIPS tests indicate that all variables, with the exception of Import, have a unit root when we consider the levels. However, after difference Export, Govcons, Inv and Privcons become stationary implying that these variables are integrated of order one, i.e., I(1). However, in order to make estimated coefficients comparable across all GDP components, we include first differences of all of them, including Import. With regard to the lag selection, as Panel B shows, both the robust BIC and the sequential GS suggest a lag of 3 in all our specifications. $^{3}$

Next we discuss the results related to the dynamic response of our macroeconomic variables to the hurricane shocks. Figures 2-6 depict the impulse responses to a hurricane shock, while Table 3 provides outcomes for specific moments after the shock. Before starting the discussion of the results, it is worth stressing that statistical significance of our mean estimates, as it is standard practice in the VAR literature, are determined by the same

\footnotetext{
${ }^{3}$ Given the time span of the data and the number of parameters to estimate, the maximum lag was set to 4 , which, indeed, should be enough to capture the dynamic effect of the hurricane shocks.
} 
confidence bands use to plot the impulse response functions. The quantitative values of the different bands for each GDP component at the $95 \%$ confidence level are reported in Table 3. It is clear from the results in Table 3 and Figure 2 that on impact Export declines, albeit this effect is statistically significant only 2 years after the shock and amounts to a decline of 2.6 percentage points. This result is in line with the literature. More precisely, natural disasters are expected to reduce export because of a fall in local production capacity and a disruption to transportation infrastructure. The fact that export may not be immediately affected after a hurricane strikes may be because countries might export products that have been stored in previous years. Indeed there is some evidence that such a lagged reaction may not be unusual. For instance, da Silva and Cernat (2012) used a gravity model and found that for small developing countries export was affected in the year of the strike and two years after. For the Caribbean, agricultural export (primary and processed) were negatively affected in the year of a hurricane event and up to one year after (Mohan 2017a), while banana export was negatively affected in the year of a strike and up to three years thereafter (Mohan 2017b). Heger et al. (2008) also discovered a lagged negative impact of natural disasters on export, albeit one rather than two years after for the region. The lagged negative impact on export for the Caribbean may be because of its export composition, in particular the fact that many countries in the region over the period of analysis were sugar exporters. Crowards (2000) used average annual growth in export before and after hurricane events for the region and found that sugar exporting countries experienced a greater reduction in export in the year after a hurricane strikes. ${ }^{4}$ Similarly, Mohan and Strobl (2013) used historical data and concluded that hurricanes have a lagged negative impact (year of the strike and up to two

\footnotetext{
${ }^{4}$ This is expected since sugar is generally harvested in the Caribbean from January to May, so that hurricane damage may only appear via a reduction in sugar export in the following year.
} 
years after) on sugar export.

The estimated impact of hurricane destruction on Import is positive (an increase of 3.2 percentage points) and statistically significant in the year of the hurricane event, and then becomes negative subsequently (decreasing by 1.7 percentage points), as can be seen in Figure 3 and Table 3. The immediate increase in import may be to meet local consumption requirements and reconstruction and rehabilitation goods, given the fall in local productive capacity and the region's high dependency on import for the majority of goods consumed. The lagged decrease in import may be attributed to a medium term reduction in economic activity and disposable income thereby reducing the demand for foreign goods. In this regard, Crowards (2000) similarly found that import for the Caribbean had a large increase during the year of a hurricane event, with a fall in the following year. Heger et al. (2008) showed that for the region import increased in the year of a natural disaster strike, and in the following year, but decreased two and three years after.

The results of Table 3 and Figure 4 show that the immediate impact of hurricane strikes on Govcons is positive (an increase of 1.4 percentage points in the year of a strike) and statistically significant. However, this effect becomes statistically insignificant a month after the initial impact. This finding is consistent with the results reported previous studies, including Melecky and Raddatz (2011) and Ouattara and Strobl (2013). The increase in Govcons could be explained by the cost of clean-up activities in the days following the disaster "as well as governments paying to provide shelter and other support for those who are unemployed, injured, or seriously affected" (Ouattara and Strobl 2013, 109). Other studies on the impact of hurricanes on government consumption however give opposite results and the literature remains unclear empirically (Melecky and Raddatz 2011 and Noy and Nualsri 2011). In the Caribbean Crowards (2000) concluded that government expenditure is highly volatile 
and this makes it difficult to quantify changes caused by natural disasters and this view was echoed by Rasmussen (2004). Auffret (2003), on the other hand, found that a natural disaster event leads to a moderate decline in government expenditure in a sample of Latin American and Caribbean countries. Noy and Nualsri (2011) showed that government expenditure increased in developed countries, but decreased in developing countries after a natural disaster. For Melecky and Raddatz (2011) whether government expenditure increased after a natural disaster depend on the development of a country's financial markets and debt levels. More generally, Noy and Nualsri (2011) argued that the cost of short-term survival and longterm reconstruction needs following a natural disaster may be hampered by logistical expenses, which may have an adverse impact on government spending. Furthermore, government expenditure may be smaller if reconstruction costs following a natural disaster are lower if the capital destroyed was no longer necessary or obsolete, and is now cheaper to replace.

With regard to Inv, our results (shown in Table 3) suggest that the instantaneous effect of the hurricane shock is first positive (an increase of 4.6 percentage points) and statistically significant; but subsequently becomes negative (declining by 0.3 percentage points) and significant 2-years after the initial impact. This pattern is also evident from the ensuing impulse response function for Inv in Figure 5. One possible explanation for this may be that the magnitude of the reconstruction effort in the year of the hurricane strike may have been sufficient to cause an initial increase in investment by drawing on savings, following a subsequent decrease to replenish savings. Existing studies for the region have found both evidence of an increase and a decrease in investment following a natural disaster. For the Caribbean and Latin America, Auffret (2003) showed that natural disasters resulted in a substantial decline in investment in the year of the strike. On the other hand, Rasmussen 
(2004) found an increase in investment in the year of the disaster strike for Eastern Caribbean countries.

Finally, for private consumption it can be seen in Table 3 and Figure 6 that Privcons responds negatively to hurricane shocks, although this negative effect only becomes statistically significant 3 years after the shock (amounting to a decline of 0.7 percentage points). Perhaps one explanation for the absence of statistical significance immediately following a hurricane strike is that the region is a major recipient of remittances, where the inflow of remittances may be amplified following a natural disaster. Additionally, persons may dip into their savings for initial reconstruction activities as soon as the natural disaster strikes; following which consumption may be reduced given a reduction in incomes and assets. In this regard Auffret (2003) found that consumption is negatively affected following a natural disaster in Latin America and the Caribbean.

One can also consider the results across components to indicate what these would imply for the net impact on the economy by examining the relative contributions of the significant factors, and we provide these calculations in the last row of Table 3. In the year of the strike the results show an increase in import and an increase in investment. Since import act to pull down GDP and investment to increase it, the relative size of the coefficients suggest that the boosting effect of investment would tend to result in an overall small positive impact (1.4 percentage points). This would be followed by a continued small impact (1.7 percentage points) in the year following a strike due to the reduction in import. However, by the second year of the event the fall in both export and investment would suggest that overall GDP should fall by 2.4 percentage points. Similar reductions, although substantially smaller, might continue into the fourth year after the strike, resulting in a 0.4 percentage point fall. 
One weakness of our hurricane destruction index is that because population figures are only available only every 10 years we need to interpolate between these decennial to derive annual values. Feasibly this may be introducing some endogeneity since a year's population estimate, except for the year that follows the actual available data, will depend to some extent on a population estimate in the future, which in turn could be affected by the hurricane events themselves. To investigate whether this could be driving our results we instead simply used as weights the share of population from the most recent past data point available. One should note that while this ensures that weightings will be free of any future population adjustments it will inevitably introduce more measurement error into the weights, particularly for those years further away from the data years available. Figures 7-11 summarises the results related to the dynamic responses of our various GDP components and depict the ensuing impulse response functions, using the hurricane index with these alternative weights. As can be seen, these results are quite similar to those reported using the interpolated weighting. The only slight difference is that the dynamic response of import becomes has become more significant (in statistical terms).

\section{Section V: Conclusion}

The empirical evidence on the impact on natural disasters on GDP in the current literature is ambiguous. One of the reasons for this may be because the components underlying GDP are not affected uniformly by these negative shocks. In this paper we investigate this possibility by constructing a large cross-country panel of annual measures of national income components and hurricane destruction for the Caribbean for over 50 years. We employed a panel VARX model, which allows for direct as well feedback effects of the storms on the GDP components. The data set unearths considerable component response heterogeneity. More specifically, export is negatively affected, but only to a statistically discernable level two years 
after a hurricane strike. Import, in contrast, tends to initially expand and then subtracts after the event. Investment similarly follows a pattern of increase and then reversal. Government consumption expenditure increases in the year of a strike and private consumption reacts negatively to hurricane destruction three years later. If we consider our results jointly then they suggest that GDP may initially slightly increase by a hurricane to later contract.

More generally, our study adds to the literature on whether disasters cause significant macroeconomic impacts and are truly a potential impediment to economic development. Studies in the exisitng literature have generally not investigated the impact of natural disasters as part of an underlying system of macroeconomic activity, thereby allowing for the possibility of interdependencies and feedback effects among GDP components. These studies thus arguably offer an inconclusive picture regarding the sign of the impacts on GDP and whether these impacts are transitory or permanent. In this paper our panel VARX model allows us to incorporate the direct effect of hurricanes on each component and also capture feedback effects within the whole system. More generally, our conclusions from the impact of hurricanes on national income components can be extended to other types of natural disasters since all types of natural disasters act as an unexpected external shock to a country's physical and human capital, thereby affecting GDP through its components. The results here demonstrate that the impact of natural disasters may be more complex once one goes beyond aggregate measures. In view of this, the general lack of consensus on the impact of natural disasters on GDP in the empirical literature may not be surprising, as countries' importance of individual GDP components and their ability to respond to large negative shocks may differ substantially. 


\section{References}

Albala-Bertrand, Jose Miguel. 1993. "Natural Disaster Situations and Growth: A Macroeconomic Model for Sudden Disaster Impacts." World Development 21 (9): 1414-1434.

Anbarci, N., Monica Escaleras and Charles A. Register. 2005. "Earthquake Fatalities: The Interaction of Nature and Political Economy." Journal of Public Economics 89(9-10): 19071933.

Auffret, Philippe. 2003. "High Consumption Volatility: The Impact of Natural Disasters?" Working Paper 2962, World Bank Policy Research, The World Bank, Washington, USA.

Bertinelli, Luisito and Eric Strobl. 2013. "Quantifying the Local Economic Growth Impact of Hurricane Strikes: An Analysis from Outer Space for the Caribbean." Journal of Applied Meteorology and Climatology 52: 1688-16971 DOI: 10.1175/JAMC-D-12-0258.

Boose, Emery, Mayra I. Serrano, and David R. Foster. 2004. "Landscape and Regional Impacts of Hurricanes in Puerto Rico." Ecological Monograph 74 (2): 335-352. doi:org/10.1890/024057.

Briguglio, Lino, Gordon Cordina, and Nadia Farrugia, and Stephanie Vella. 2006. Conceptualising and measuring economic resilience. In Lino Briguglio, Gordon Cordina, and E. Kisanga, E. (Eds.), Building the Economic Resilience of Small States 265-288. Malta: Islands and Small States Institute in collaboration with the Commonwealth Secretariat.

Carter, Michael, Peter D. Little, Tewodaj Mogues and Workneh Negatu. 2007. "Poverty Traps and Natural Disasters in Ethiopia and Honduras." World Development 35(5): 835-856.

Centro Internacional de Agricultura Tropical (CIAT), United Nations Environment Program (UNEP), Center for International Earth Science Information Network (CIESIN), Columbia University, and the World Bank (2005) Latin American and Caribbean Population Database. Version 3. Available from http://www.na.unep.net/datasets/datalist.php3 or http://gisweb.ciat.cgiar.org/population/dataset.htm

Crowards, Tom. 2000. "An Index of Inherent Economic Vulnerability for Developing Countries." Working Paper 6/00, Caribbean Development Bank, Barbados.

da Silva, Jorge Andrade and Cernat Lucian, 2012. "Coping with loss: the impact of natural disasters on developing countries' trade flows." DG TRADE Chief Economist Notes 2012-1, Directorate General for Trade, European Commission.

Easterly, William, and Aart C. Kraay. 2000. "Small States, Small Problems? Income, Growth, and Volatility in Small States." World Development 28 (11): 2013-2027.

Elliott, R., S. Puyang, and E. Strobl. 2015. "The Local Impact of Typhoons on Economic Activity in China: A View from Outer Space." Journal of Urban Economics 88: 50-66. 
Emanuel, Kerry. 2011. "Global Warming Effects on U.S. Hurricane Damage." Weather Climate and Society DOI: http://dx.doi.org/10.1175/WCAS-D-11-00007.1

Everaert, Gerdie, and Lorenzo Pozzi. 2007. "Bootstrap-based bias correction for dynamic panels." Journal of Economic Dynamics and Control 31(4): 1160-1184.

Gassebner, Martin, Alexander Keck, and Robert Teh. 2010. "Shaken, not Stirred: The Impact of Disasters on International Trade." Review of International Economics 18 (2): 351-368.

Han, Chirok, Peter C. B. Phillips, and Donggyu Sul. 2017. "Lag length selection in panel autoregression." Econometric Review 36(1-3): 225-240.

Heger, Martin, Alex Julca, and Oliver Paddison. 2008. "Analysing the Impact of Natural Hazards in Small Economies: The Caribbean Case." UNU/WIDER Research Paper 2008/25, World Institute for Development Economics Research, Helsinki, Finland.

Hochrainer, Stefan. 2009. "Assessing the Macroeconomic Impacts of Natural Disasters. Are there Any?" Working Paper 4968, World Bank Policy Research, The World Bank, Washington, USA.

Hsiang, Solomon, M. 2010. "Temperatures and cyclones strongly associated with economic production in the Caribbean and Central America." Proceedings of the National Academy of Sciences of the United States of America 107(35): 15367-15327.

Judson, Ruth, A and Ann, L. Owen. 1991. "Estimating dynamic panel data models: a guide for macroeconomists." Economics Letters 65(1): 9-15.

Kahn, Mathew. 2005. "The Death Toll from Natural Disasters: The Role of Income, Geography and Instituions." The Review of Economics and Statistics 87(2):271-284.

Kiviet, Jan, F. 1995. "On Bias, Inconsistency, and Efficiency of Various Estimators in Dynamic Panel Data Models." Journal of Econometrics 68(1): 53-78.

Klomp, Jeroen and Kay Valckx. 2014. "Natural disasters and economic growth: A metaanalysis." Global Environmental Change 26(1):183-195.

International Center for Tropical Agriculture (CIAT). 2016. Latin American and Caribbean Population Database.http://gisweb.ciat.cgiar.org/population/report.htm

Levin, Andrew, Chien-Fu Lin and Chia-Shang James Chu. 2002. "Unit Root Tests in Panel Data: Asymptotic and Finite-sample Properties." Journal of Econometrics 108(1): 1-24.

Loayza, Norman, Eduardo Olaberría, Jamele Rigolini, and Luc Christiansen. 2012. "Natural Disasters and Growth-Going Beyond the Averages." World Development 40(7):1317-1336.

Melecky, Martin and Claudio Raddatz. 2011. How Do Governments Respond after Catastrophes? Natural-Disaster Shocks and the Fiscal Stance, The World Bank Policy Research Working Paper 5564.

Mohan, Preeya. 2017a. "Impact of Hurricanes on Agriculture: Evidence from the Caribbean." Natural Hazards Review 18(3): 1-13.. 
Mohan, Preeya. 2017b. "The Economic Impact of Hurricanes on Bananas: A Case Study of Dominica Using Synthetic Control Methods." Food Policy 68: 21-30.

Mohan, Preeya and Eric Strobl. 2013. "The Economic Impact of Hurricanes in History: Evidence from Sugar ExportsExport in the Caribbean from 1700 to 1960." Weather Climate and Society $5(1): 5-13$.

National Hurricane Center (NHC). 2016. North Atlantic Hurricane Database (HURDAT). http://www.aoml.noaa.gov/hrd/hurdat/Data_Storm.html

Narayan, P.,K. 2003. "Macroeconomic Impact of Natiral Disasters on a Small Island Economy: Evidene from a CGE model." Applied Economic Letters 10(11): 721-723.

Nickell Stephen. 1981. "Biases in dynamic models with fixed effects." Econometrica 49(6): 1417-1426.

Noy, Ilan. 2009. "The Macroeconomic Consequences of Disasters." Journal of Development Economics 88 (2): 221-231.

Noy, Ilan, and Aekkanush Nualsri. 2007. "What do Exogenous Shocks tell us about Growth Theories?" Working Paper 07-28, University of Hawaii, Hawaii, USA.

Noy, Ilan and Aekkanush Nualsri. 2011. "Fiscal Storms: Public Spending and Revenues in the Aftermath of Natural Disasters." Environment and Development Economics 16 (1): 113-128.

Ouattara, Bazoumana and Eric Strobl. 2013. "The fiscal implications of hurricane strikes in the Caribbean." Ecological Economics 85(C): 105-115.

Penn World Tables (PWT). 2016. Groningen Growth and Development Centre. http://www.rug.nl/ggdc/productivity/pwt/

Pesaran, M. Hashem. 2007. "A Simple Panel Unit Root Test in the Presence of Cross-section Dependence." Journal of Applied Econometrics 22(2): 265-312.

Pesaran, M. Hashem, and Zhongyun Zhao, Z. 1999. "Bias Reduction in Estimating Long-run Relationships from Dynamic Heterogeneous Panels," in Hsiao, C. , Lahiri, K., Lee, L.F. and Pesaran, M.H. (eds), Analysis of Panels and Limited Dependent Variables: A Volume in Honour of G S Maddala, Cambridge University Press, Cambridge, chapter 12.

Raddatz, Claudio, 2007. "Are external shocks responsible for the instability of output in lowincome countries?." Journal of Development Economics 84(1): 155-187.

Rasmussen, Tobias N. 2004. "Macroeconomic Implications of Natural Disasters in the Caribbean." Working Paper 04/224, The International Monetary Fund, Washington, USA.Skidmore, Mark, and Hideki Toya. 2002. "Do Natural Disasters Promote Long-run Growth?" Economic Inquiry 40 (4): 664-687.

Skidmore, Mark and Hideki Toya. 2002. "Do Natural Disasters Promote Long run Growth." Economic Inquiry 40(4): 664-687.

Skidmore, Mark and Hideki Toya. 2007. "Economic Development and the Impacts of Natural Disasters." Economics Letters 94(1):20-25. 
Strobl, Eric. 2012. "The Macroeconomic Impact of Natural Disasters in Developing Countries: Evidence from Hurricane Strikes in the Central American and Caribbean Region." Journal of Development Economics 97 (1): 130-141. 


\section{Appendix}

We used Boose et al.'s (2004) version of the well-known Holland (1980) wind field model. More specifically, the wind experienced at time $t$ due to hurricane $k$ at any point $P=j$, i.e., $W_{j k}$ is given by:

$W_{j, k, t}=G F\left[V_{m, k, t}-S\left(1-\sin \left(T_{i, k, t}\right)\right) \frac{V_{h, k, t}}{2}\right]\left[\left(\frac{R_{m, k, t}}{R_{i, k, t}}\right)^{B_{j t}} \exp \left(1-\left(\frac{R_{m, k, t}}{R_{i, k, t}}\right)^{B_{j t}}\right)\right]^{\frac{1}{2}}$

where $V_{m}$ is the maximum sustained wind velocity anywhere in the hurricane, $T$ is the clockwise angle between the forward path of the hurricane and a radial line from the hurricane center to the pixel of interest, $P=j, V_{h}$ is the forward velocity of the hurricane, $R_{m}$ is the radius of maximum winds, and $R$ is the radial distance from the center of the hurricane to point $P$. The remaining variables in (A1) consist of the gust factor $G$ and the scaling parameters $F, S$, and $B$, for surface friction, asymmetry due to the forward motion of the storm, and the shape of the wind profile curve, respectively.

In terms of implementing (A1), one should note that $V_{m}$ is given by the storm track data described in the data section, $V_{h}$ can be directly calculated by following the storm's movements between locations along its track, and $R$ and $T$ are calculated relative to the point of interest $P=j$. All other parameters have to be estimated or assumed. We have no information on the gust wind factor $G$, but a number of studies (e.g., Paulsen and Schroeder, 2005) have measured $G$ to be around 1.5 , and we also used this value. For $S$ we followed Boose et al. (2004) and assumed it to be 1. While we also do not know the surface friction to directly determine $F$, Vickery et al. (2009) noted that in open water the reduction factor is about 0.7 and reduce by $14 \%$ on the coast and $28 \%$ further $50 \mathrm{~km}$ inland. We thus adopted a reduction factor that linearly decreases within this range as we considered points $i$ further 
inland from the coast. To determine $B$ we employed Holland's (2008) approximation method, whereas we used the parametric model estimated by Xiao et al. (2009) to estimate $R_{\max }$. Finally, as set of points, $j=1, \ldots J$ we took the centroid of the grid cells of the Latin American and Caribbean Population database described in Section II. 
Table 1: Summary Statistics

\begin{tabular}{|l|l|l|l|l|}
\hline Variable & Mean & $\begin{array}{l}\text { Standard } \\
\text { deviation }\end{array}$ & Minimum & Maximum \\
\hline Export & 24,392 & 62,537 & 10 & 385,862 \\
\hline Import & 29,459 & 78,416 & 12 & 517,119 \\
\hline Govcons & 7,494 & 18,428 & 6 & 115,353 \\
\hline Inv & 15,814 & 42,798 & 4 & 250,306 \\
\hline Privcons & 56,661 & 150,968 & 10 & $1,299,903$ \\
\hline$f$ & 0.21 & 0.41 & 0 & 3.68 \\
\hline$f 2$ & 0.22 & 0.41 & 0 & 0.69 \\
\hline
\end{tabular}

Source: Authors' Calculation.

Table 2: Panel unit root and lag selection tests

\begin{tabular}{|c|c|c|c|c|c|}
\hline \multicolumn{6}{|c|}{ Panel A-unit root tests } \\
\hline & \multicolumn{2}{|l|}{ LLC } & \multicolumn{2}{|l|}{ CIPS } & \\
\hline & Test-stat & $p$-values & Test-stat & $p$-values & \\
\hline $\begin{array}{l}\text { Export } \\
\Delta \text { Export }\end{array}$ & $\begin{array}{l}-0.806 \\
-7.580\end{array}$ & $\begin{array}{l}0.210 \\
0.000\end{array}$ & $\begin{array}{l}-0.990 \\
-9.059\end{array}$ & $\begin{array}{l}0.161 \\
0.000\end{array}$ & $\mathrm{I}(1)$ \\
\hline $\begin{array}{l}\text { Import } \\
\Delta \text { Import }\end{array}$ & $\begin{array}{l}-1.994 \\
---\end{array}$ & $\begin{array}{l}0.02 \\
---\end{array}$ & $\begin{array}{l}-2.024 \\
---\end{array}$ & $\begin{array}{l}0.021 \\
---\end{array}$ & $\mathrm{I}(0)$ \\
\hline $\begin{array}{l}\text { Govcons } \\
\Delta \text { Govcons }\end{array}$ & $\begin{array}{l}-0.244 \\
-5.526 \\
\end{array}$ & $\begin{array}{l}0.404 \\
0.000 \\
\end{array}$ & $\begin{array}{l}0.790 \\
-5.676 \\
\end{array}$ & $\begin{array}{l}0.785 \\
0.000 \\
\end{array}$ & $\mathrm{I}(1)$ \\
\hline $\begin{array}{l}\ln v \\
\Delta \operatorname{lnv}\end{array}$ & $\begin{array}{l}-0.955 \\
-19.888\end{array}$ & $\begin{array}{l}0.170 \\
0.000\end{array}$ & $\begin{array}{l}-0.412 \\
-12.569\end{array}$ & $\begin{array}{l}0.340 \\
0.000 \\
\end{array}$ & $\mathrm{I}(1)$ \\
\hline $\begin{array}{l}\text { Privcons } \\
\Delta \text { Privcons }\end{array}$ & $\begin{array}{l}-0.092 \\
-9.988\end{array}$ & $\begin{array}{l}0.463 \\
0.000\end{array}$ & $\begin{array}{l}-1.859 \\
-13.412\end{array}$ & $\begin{array}{l}0.320 \\
0.000\end{array}$ & $\mathrm{I}(1)$ \\
\hline \multicolumn{6}{|c|}{ Panel B-lag selection } \\
\hline Robust BIC & 3 & & & & \\
\hline Sequential GS & 3 & & & & \\
\hline
\end{tabular}

Source: Authors' calculations. 
Table 3: Mean Response of the macroeconomic variables to Hurricane Shocks

\begin{tabular}{|c|c|c|c|c|c|}
\hline Variables & Impact effect & Year 1 & Year 2 & Year 3 & Year 4 \\
\hline Export & -0.012 & -0.009 & $-0.026 * *$ & -0.003 & -0.000 \\
\hline $\begin{array}{l}95 \% \text { Confidence } \\
\text { band }\end{array}$ & $(-0.033,0.009)$ & $(-0.029,0.013)$ & $\begin{array}{c}(-0.047,- \\
0.003)\end{array}$ & $(-0.011,0.005)$ & $(-0.005,0.004)$ \\
\hline Import & $0.032 * *$ & $-0.017^{*}$ & -0.020 & -0.008 & -0.004 \\
\hline $\begin{array}{l}95 \% \text { Confidence } \\
\text { band }\end{array}$ & $(0.011,0.054)$ & $(-0.039,0.004)$ & $(-0.042,0.004)$ & $(-0.020,0.003)$ & $(-0.014,0.005)$ \\
\hline Govcons & $0.014 *$ & -0.004 & -0.002 & -0.004 & -0.002 \\
\hline $\begin{array}{l}95 \% \text { Confidence } \\
\text { band }\end{array}$ & $(-0.001,0.029)$ & $(-0.021,0.012)$ & $(-0.019,0.014)$ & $(-0.010,0.002)$ & $(-0.006,0.001)$ \\
\hline Inv & $0.046 * *$ & -0.017 & $-0.003 * *$ & -0.004 & -0.001 \\
\hline $\begin{array}{l}95 \% \text { Confidence } \\
\text { band }\end{array}$ & $(0.019,0.071)$ & $(-0.046,0.010)$ & $\begin{array}{c}(-0.060,- \\
0.002)\end{array}$ & $(-0.015,0.006)$ & $(-0.007,0.005)$ \\
\hline Privcons & -0.002 & -0.010 & 0.006 & $-0.007^{*}$ & $-0.004^{*}$ \\
\hline $\begin{array}{l}95 \% \text { Confidence } \\
\text { band }\end{array}$ & $(-0.021,0.018)$ & $(-0.031,0.010)$ & $(-0.014,0.026)$ & $(-0.014,0.000)$ & $\begin{array}{c}-0.008,- \\
0.000)\end{array}$ \\
\hline $\begin{array}{l}\text { Net Effect on } \\
\text { GDP: }\end{array}$ & 0.014 & 0.017 & -0.029 & -0.007 & -0.004 \\
\hline
\end{tabular}

** and * represent 5 and 10 percent significance levels, respectively. 
Figure 1: Distribution of average $\mathrm{f}$ Index

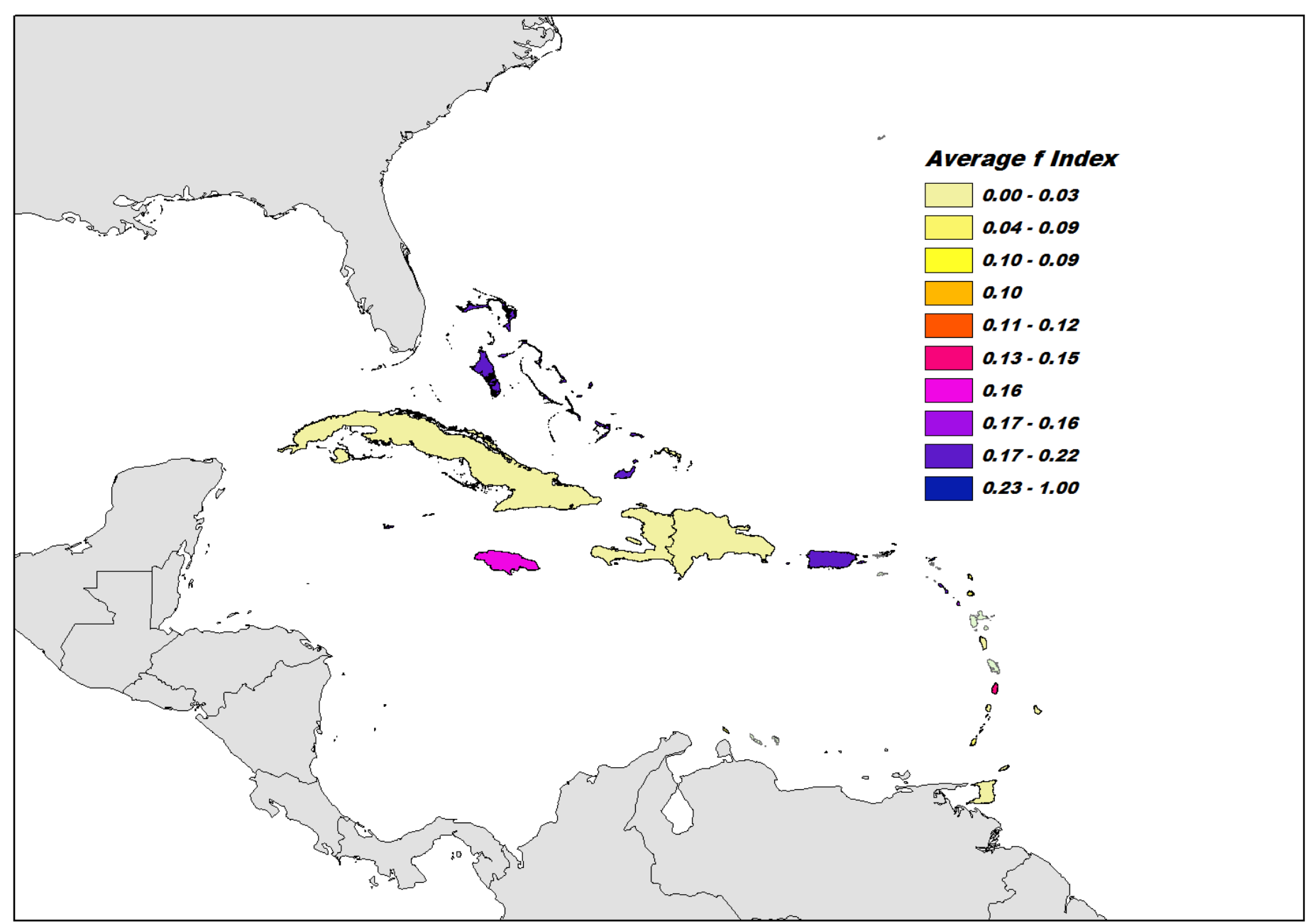


Figure 2: Dynamic responses to $f$ shocks, Export

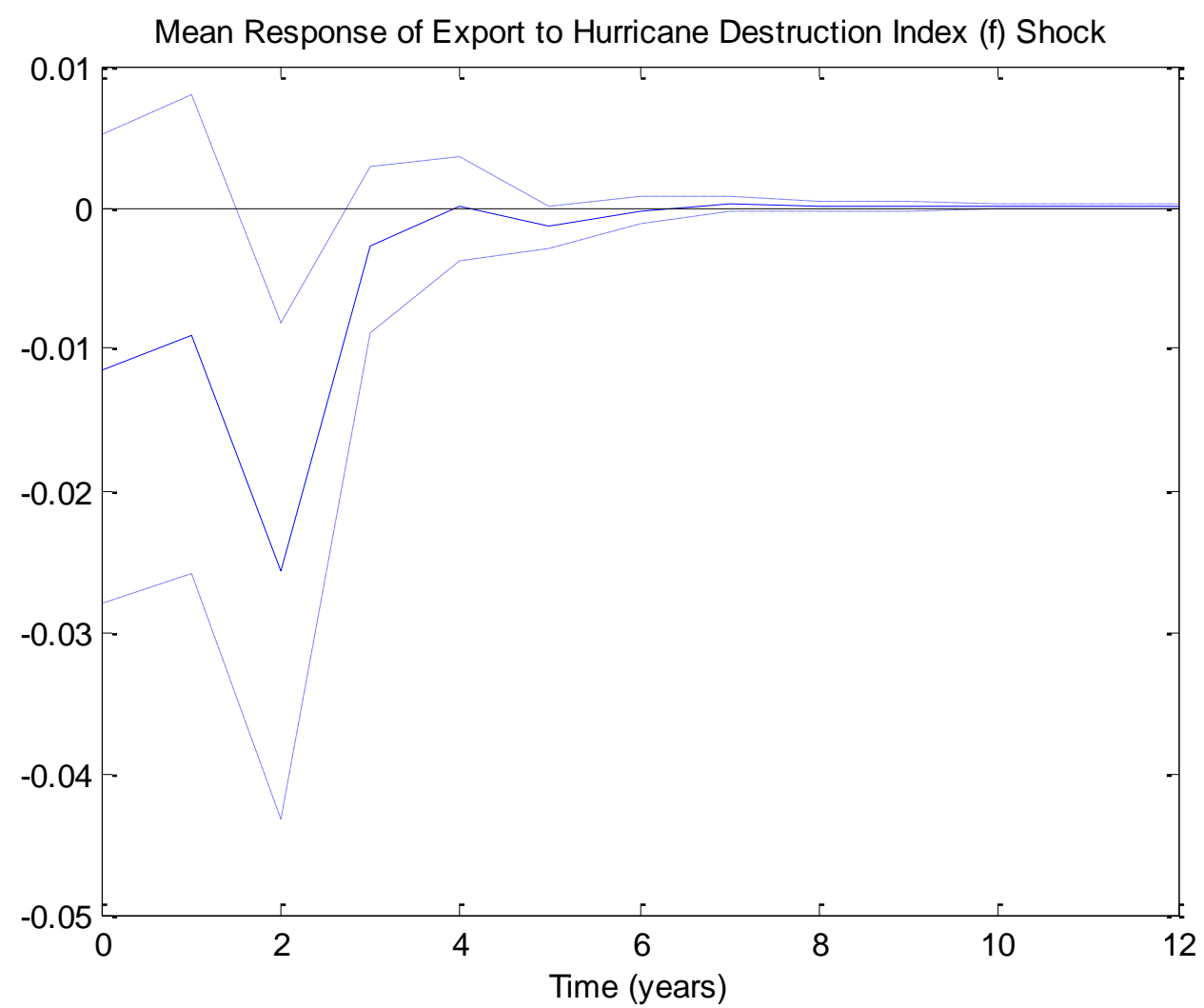

Source: Authors' calculations. 
Figure 3: Dynamic responses $f$ shocks, Import

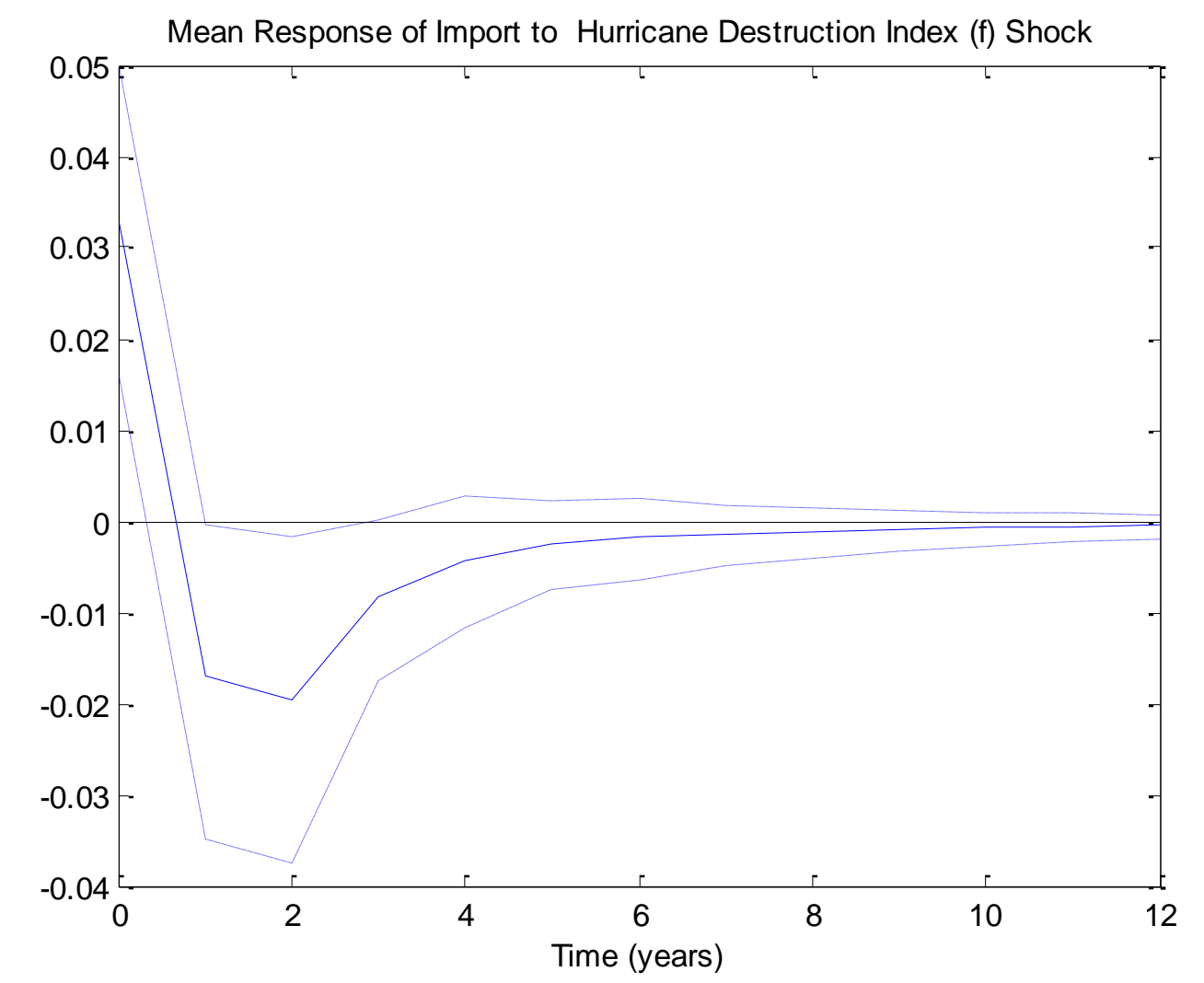

Source: Authors' calculations. 
Figure 4: Dynamic responses to $f$ shocks, Government Consumption

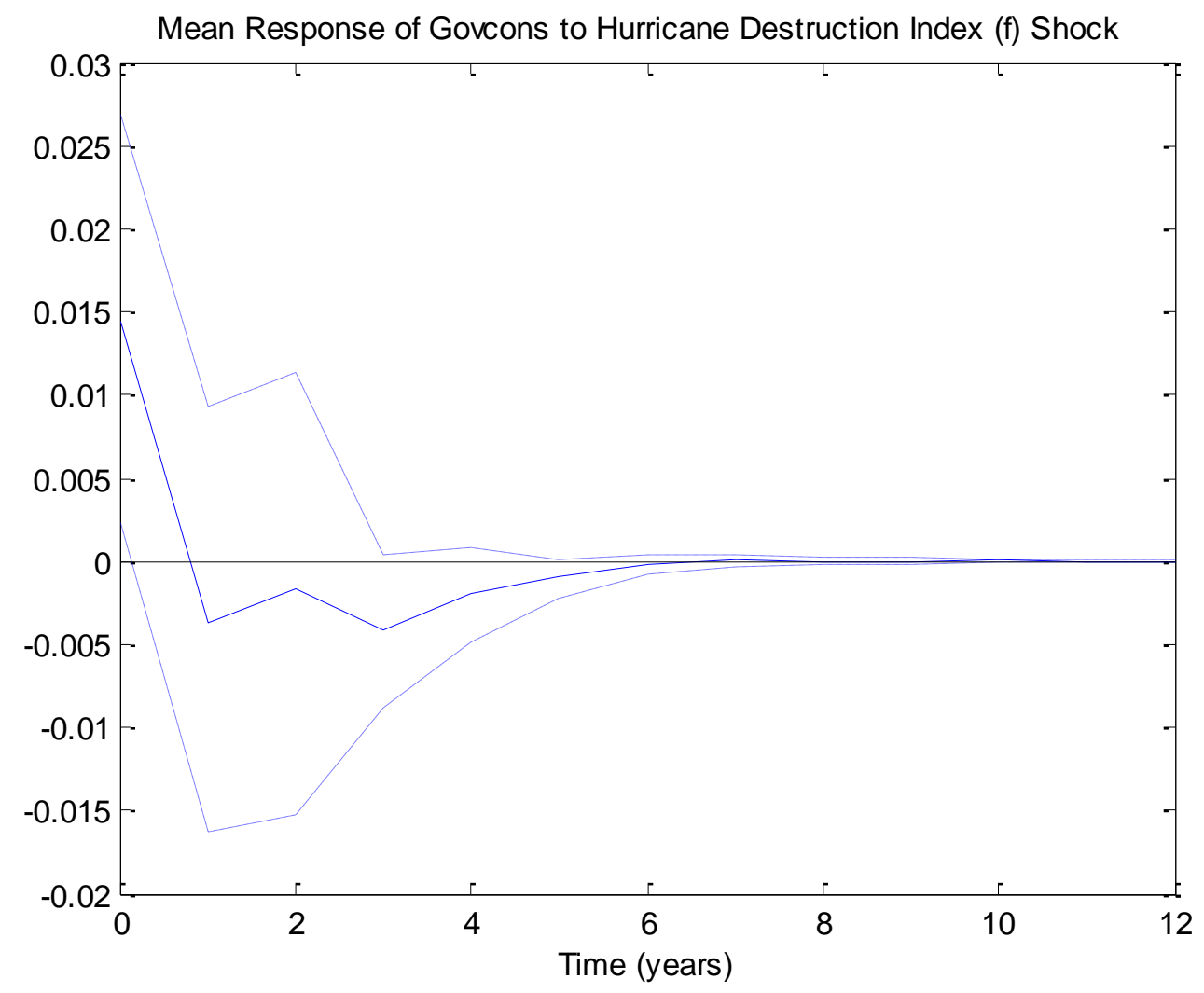

Source: Authors' calculations. 
Figure 5: Dynamic responses to $f$ shocks, Investment

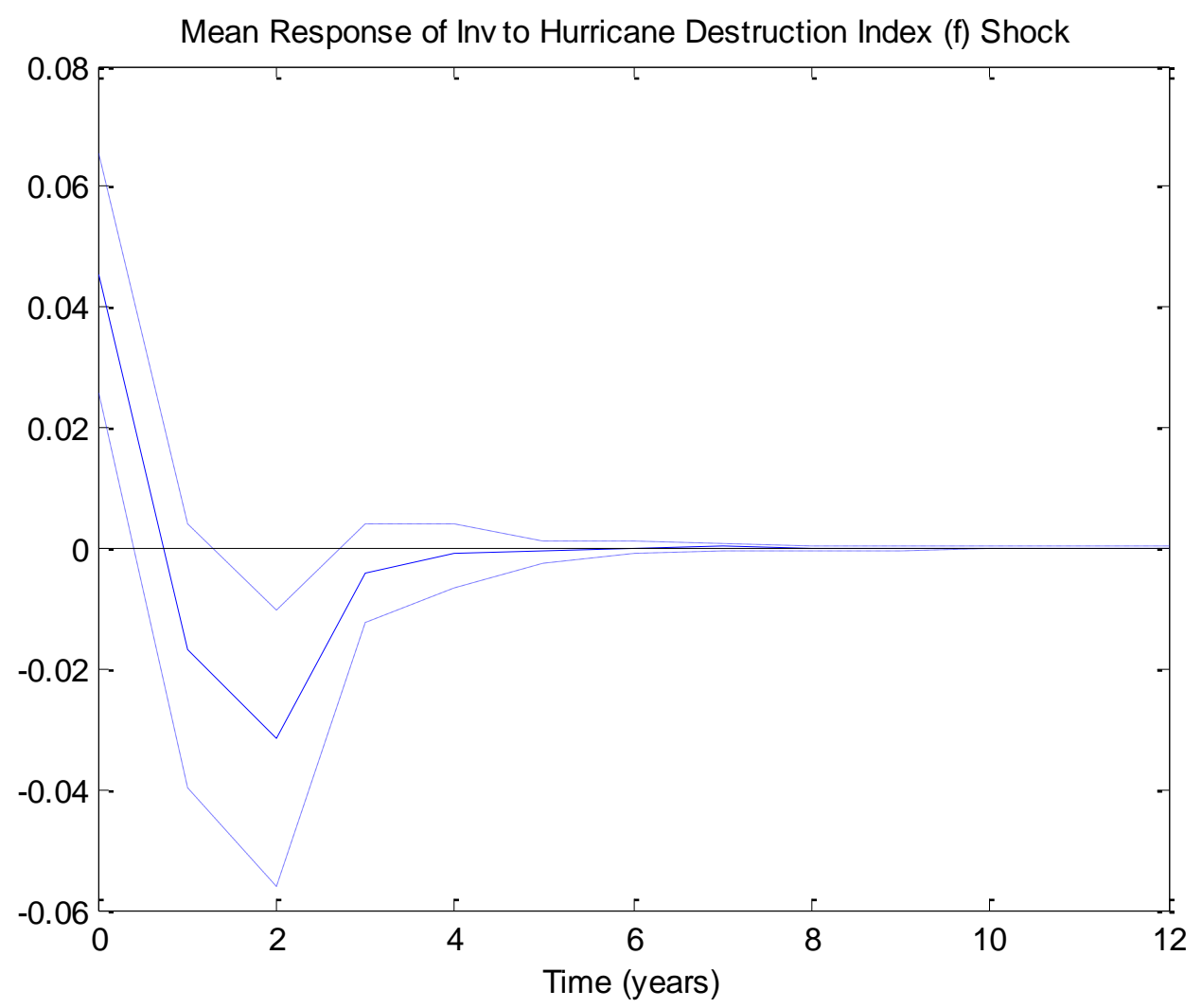

Source: Authors' calculations. 
Figure 6: Dynamic responses to $f$ shocks, Private Consumption

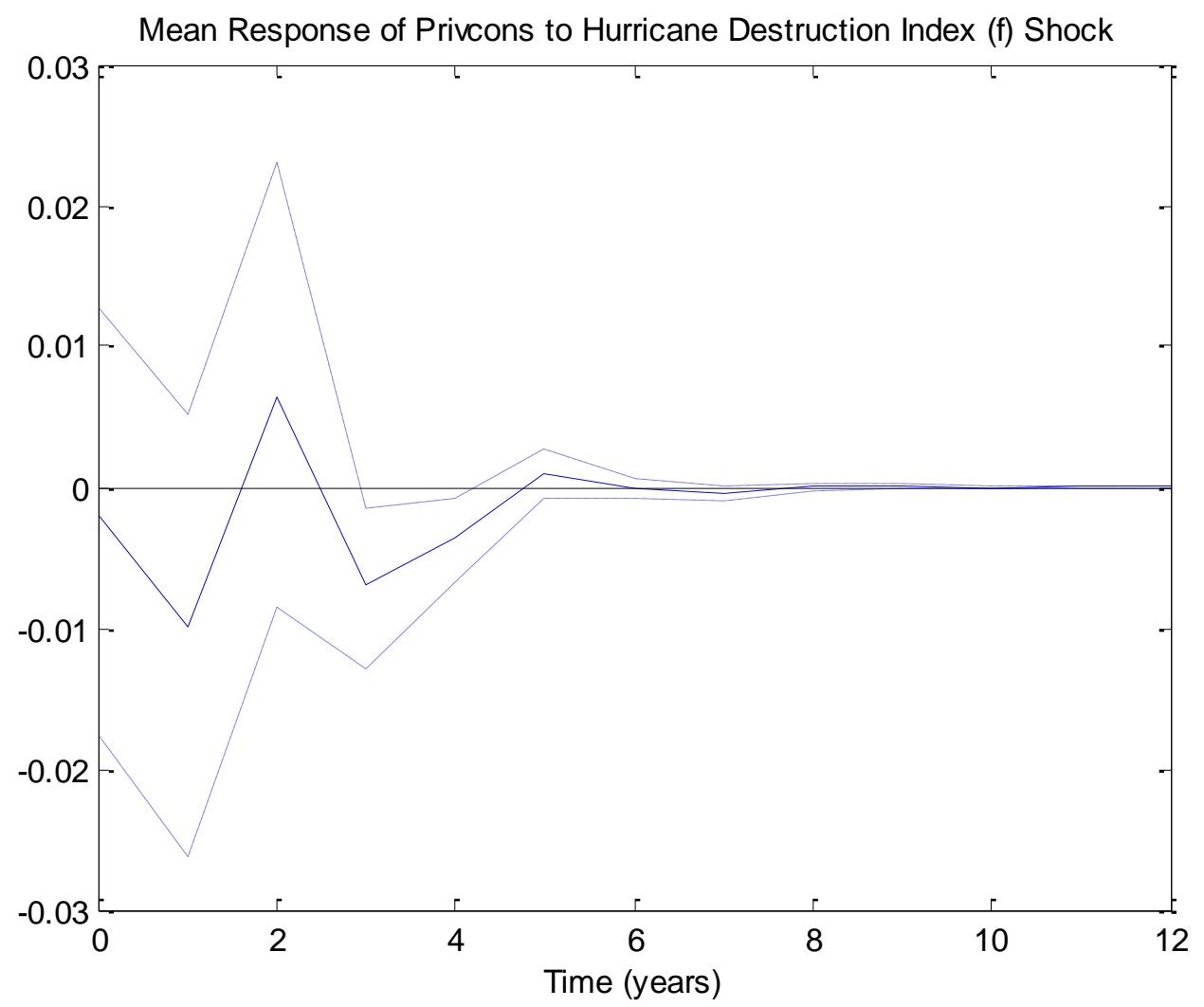

Source: Authors' calculations. 
Figure 7: Dynamic responses to $f_{2}$ shocks, Export

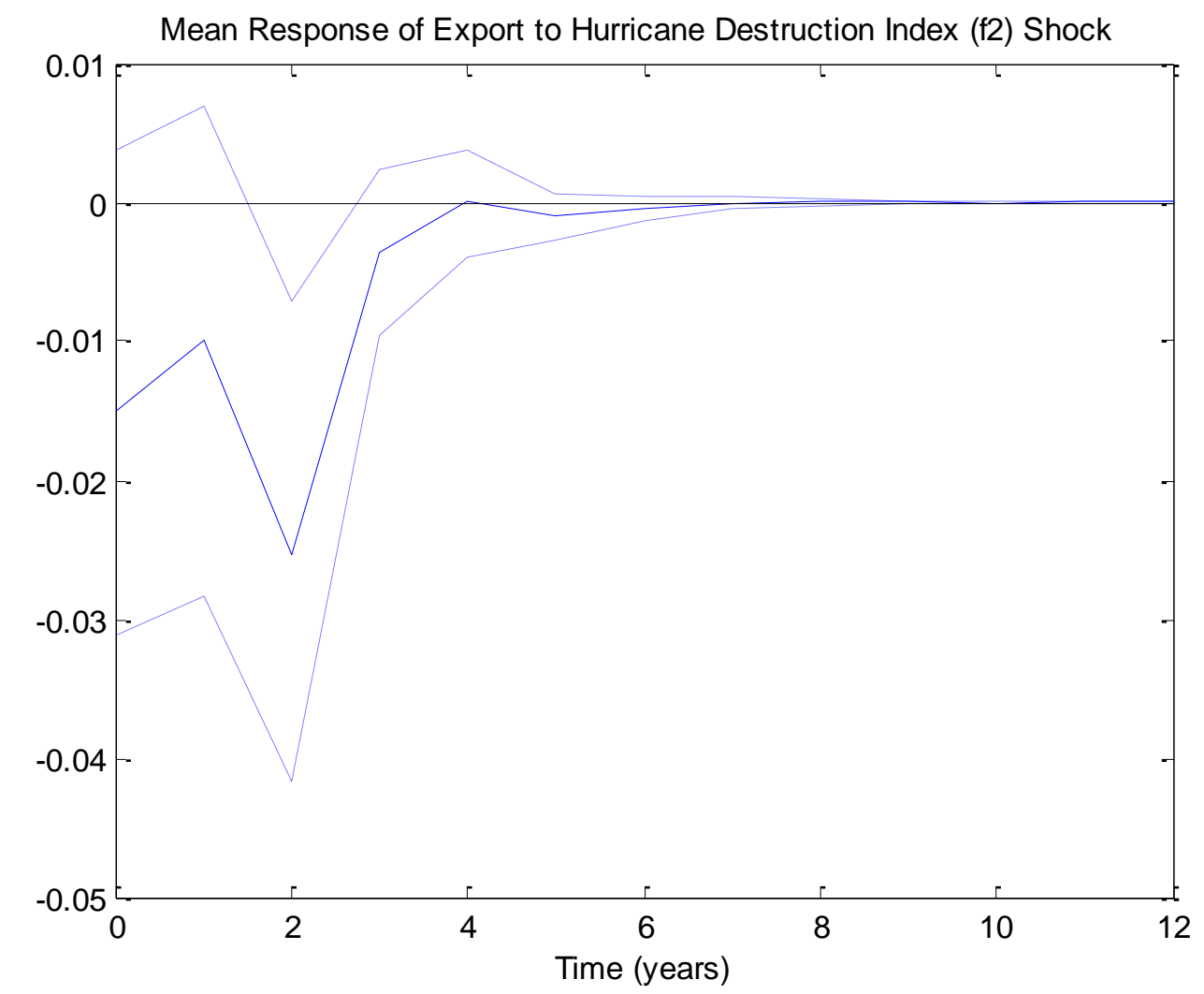

Source: Authors' calculations. 
Figure 8: Dynamic responses to $f_{2}$ shocks, Import

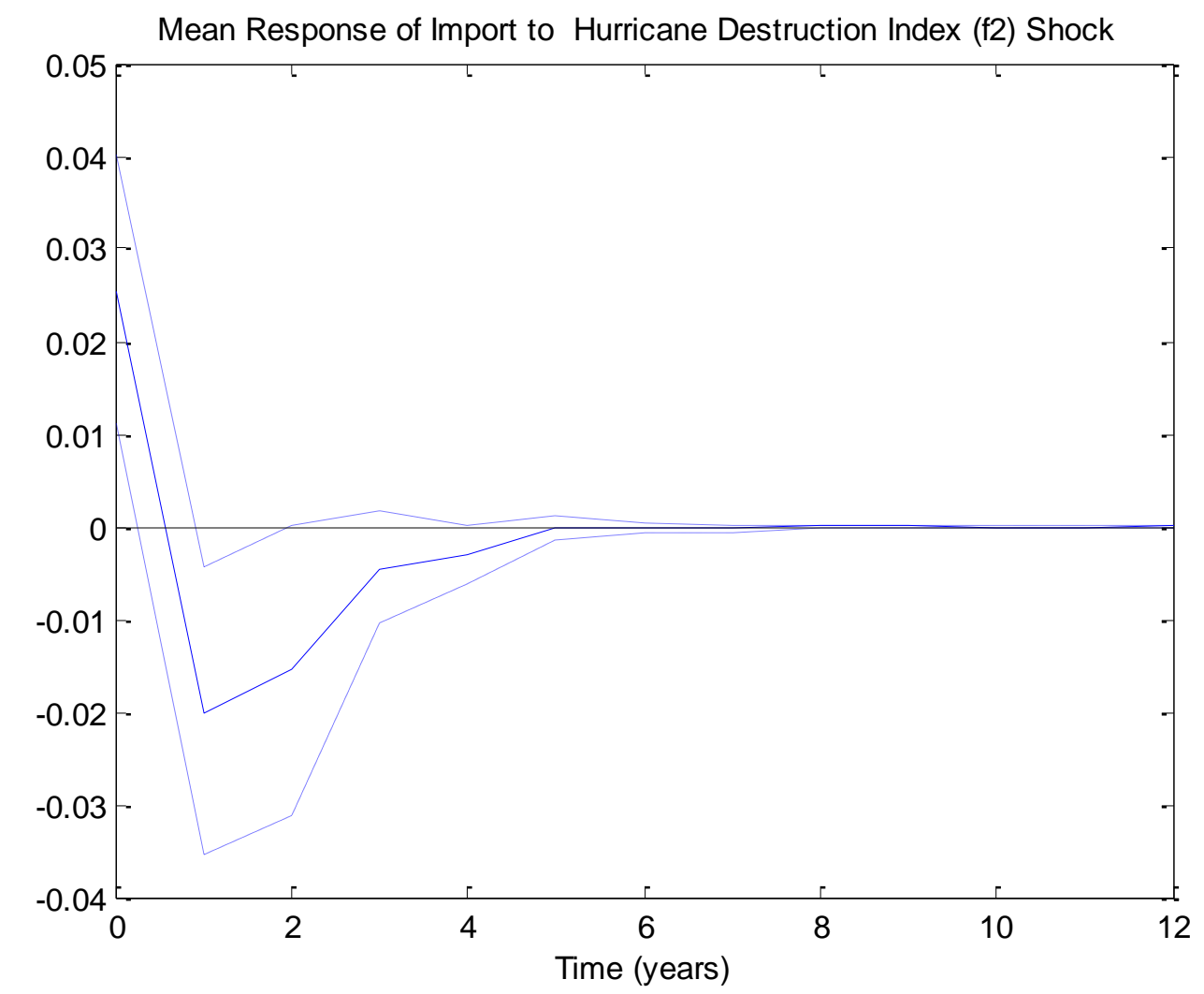

Source: Authors' calculations. 
Figure 9: Dynamic responses to $f_{2}$ shocks, Government Consumption

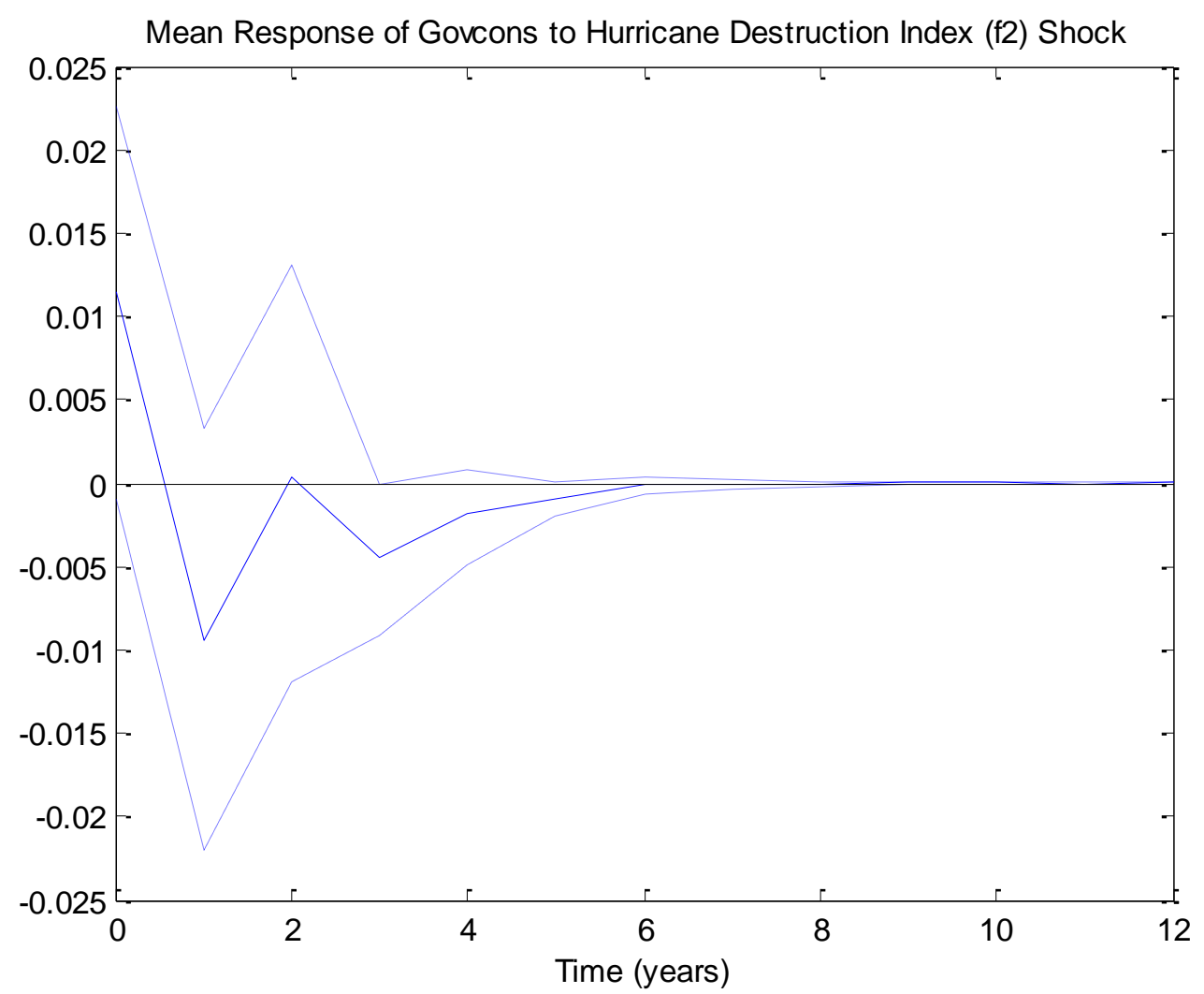

Source: Authors' calculations. 
Figure 10: Dynamic responses to $f_{2}$ shocks, Investment

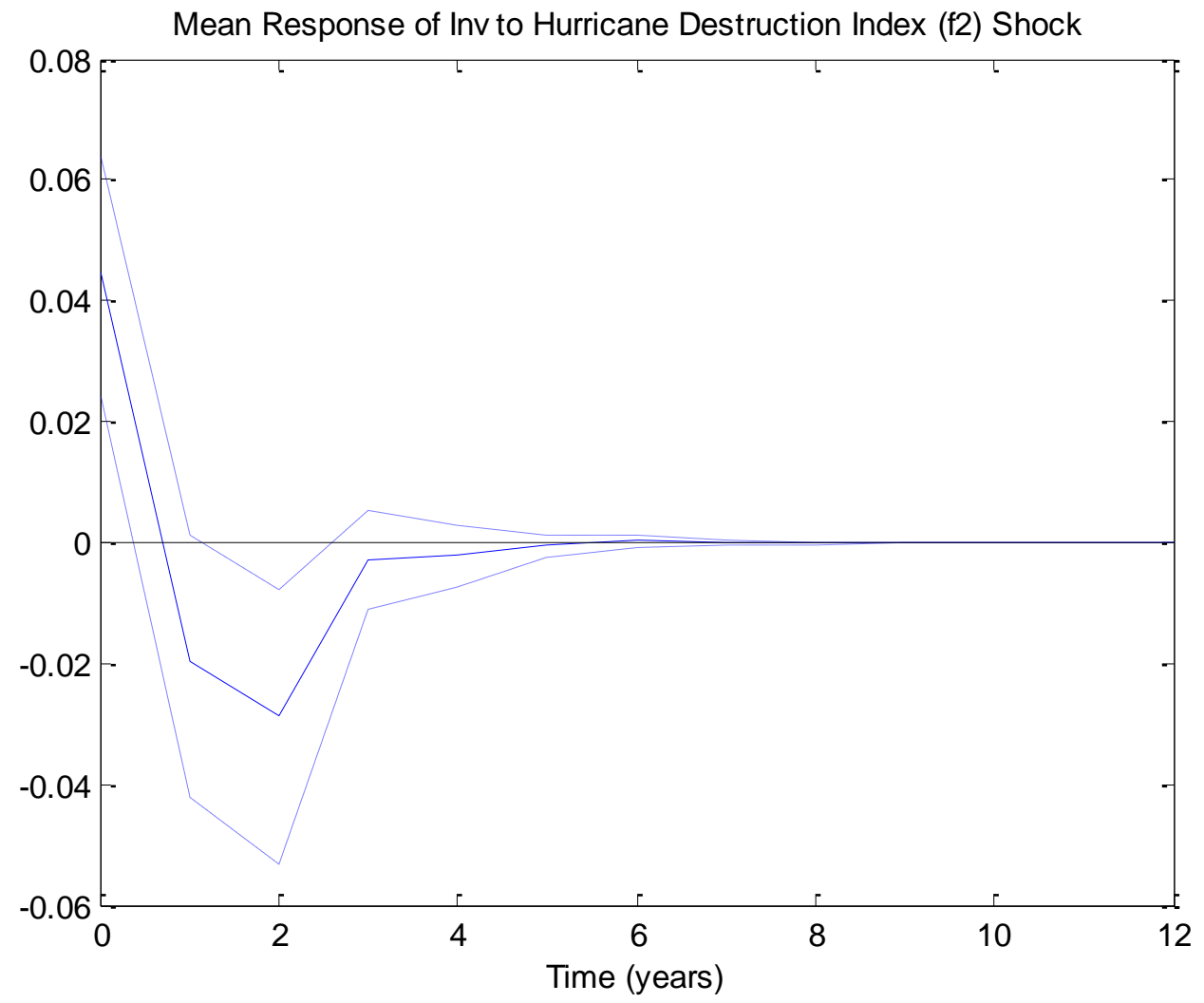

Source: Authors' calculations. 
Figure 11: Dynamic responses to $f_{2}$ shocks, Private Consumption

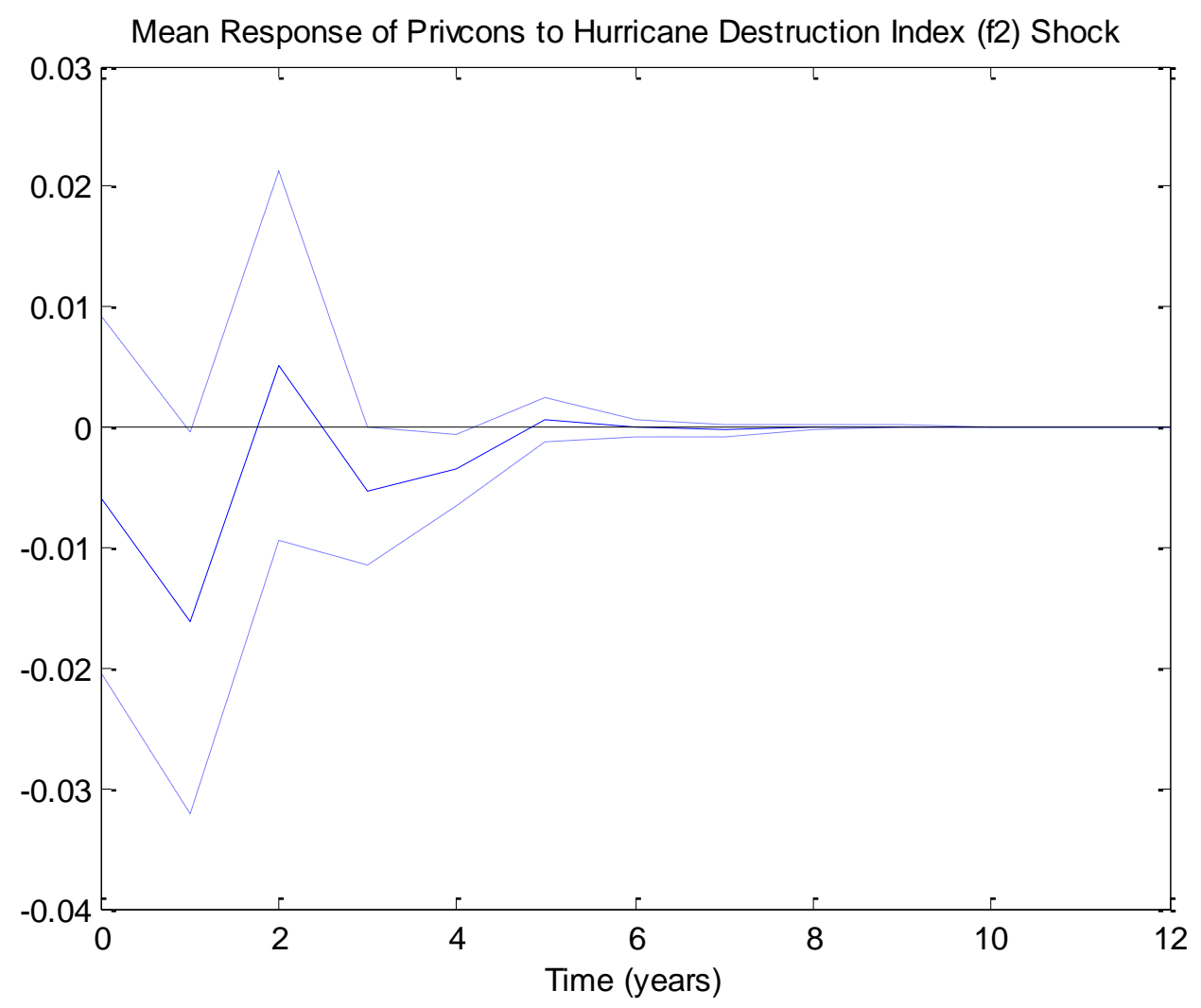

Source: Authors' calculations. 